\title{
Introduction
}

\section{China in Africa: A Relationship in Transition}

\author{
European Journal of Development Research (2009) 21, 479-484. doi:10.1057/ejdr.2009.30
}

Barely one decade ago, at the turn of the millennium, the juxtaposition of China and Africa seemed like an exercise in separate categories. The only thing that these geographical entities appeared to have in common was that they both had, in recent centuries, been economically dominated by external powers and that they both had high rates of poverty and very low per capita incomes. There were few organic, bilateral links between Africa and China, and even the indirect links were of the most tenuous nature.

Today it is inconceivable, from the African end at least, that Africa's economic and political destiny could be discussed without reference to China. From the Chinese angle, Africa may not hold a position of the same level of importance, but Africa is recognised to be a crucial source of raw materials required to support China's forthcoming investments in infrastructure and as inputs into its burgeoning manufacturing sector. The ChinaAfrica axis is not, however, solely of economic importance. There are important political alliances developing between China and Africa, often undercutting historical links with northern partners. Although there are increasing flows of people between China and Africa, cultural spillovers remain relatively muted.

The growing significance of the China-Africa relationship has led to a burgeoning 'grey' literature in the popular and business press. Unfortunately much of this is poorly informed. For example, it is widely asserted - and believed - that Chinese firms operating in Africa employ prison labour; that they make widespread use of unskilled Chinese labour remunerated at very low wage rates (below that paid to local unskilled labour), and that they use virtually no local inputs. This may be true. But it may not be the case. The information is anecdotal, and often highly prejudicial, generally generated by journalists from the west writing for an audience which is increasingly feeling the competitive pressure exerted by Chinese economic and political actors in Africa.

The research response has been slower off the ground. Three early initiatives examining the growing economic footprint of China in Africa were largely in the realm of economics. These were the networked Asian Drivers Programme (http://asiandrivers.open.ac.uk/), the World Bank's widely quoted Africa's Silk Road study (Broadman, 2007) and Jenkins and Edwards analysis of China-Africa trade undertaken for Department for International Development (DfID), the United Kingdom's aid ministry (Jenkins and Edwards, 2004). Running almost in parallel were a series of studies broadly described as addressing issues of politics, notably the works of Tull (2006); Alden (2007); Brautigam (2008) and Large et al (2008) and in anthropology/sociology (Hsu, 2007; Dobler, 2008; Ho, 2008). Some of this research surfaced in Special Issues of journals (notably World Development, Vol. 36 No. 2, 2008, and the Review of African Political Economy, Vol. 35, No. 1, 2008). Africabased research on the China-Africa relationship followed soon after, most significantly in the extensive research and policy programme conducted by the African Economic Research Consortium's Asian Driver Programme. This began with scoping studies in 18 African economies, and then developed into a second-stage of 22 more detailed country case-studies (www.aercafrica.org). ${ }^{1}$ The Centre for Chinese Studies in South Africa undertook a series of high-profile snapshot studies on Chinese firms participating in the 
construction and infrastructure sectors in Africa (www.ccs.org.za). But this is a moving frontier and there are an increasing number of researchers - in Africa and elsewhere focusing on the China-Africa relationship. Unfortunately, little of this research endeavour is based in China.

In addition to providing much primary empirical material, the distinctive contribution which this Special Issue of the European Journal of Development Research makes to this growing academic literature on China-Africa is to focus on some of its more dynamic elements, and in so doing, to begin to deconstruct the easy image of 'an Africa' and 'a China'. All of the contributions in this issue make explicit or implicit use of the Asian Drivers conceptual framework, that is that the China-Africa relationship is seen to involve a number of vectors (the most important of which are flows of trade, investment, aid and people), that they have a combination of competitive and complementary impacts, and that although many of these impacts are highly visible and direct, often the more significant impacts are those which are indirect in nature (http://asiandrivers.open.ac.uk/ Taxonomy_of_impacts.html).

More specifically, the first three of the papers in this Special Issue address trade relations between China and Africa. In summary form they draw on the Asian Driver framework as reflected in Figure 1. It shows that in cases where China exports and Africa imports, and where Africa exports and China imports, African economies stand to gain. This surfaces in direct trade relations between Africa and China. However, when China exports the same products as does Africa, or when it buys in global markets the same products as does Africa, then these indirect impacts can often be very harmful.

Ojeyide, Bankole and Adewuyi draw on the African Economic Research Consortium (AERC) Scoping Studies to chart the rapid growth in bilateral trade between Africa and China. In this they identify a series of gains to African economies. But at the same time, they observe that China's prowess in manufactures has both direct and indirect impacts, which are harmful to Africa's industrial growth. Moreover, China's demand for commodities reinforces Africa's past comparative advantage. The net result, they conclude, is that China's potential impact is harmful in freezing Africa's economic structure. They conclude with two policy implications - China needs to provide Africa with preferential market access, and to support the capacity of Africa's producers to take advantage of this access. Giovannetti and Sanfilippo consider the indirect impact on African industry of China's competences in third country markets. Utilising econometric analysis they compute a significant displacement effect in the US and European Union (EU) markets. This

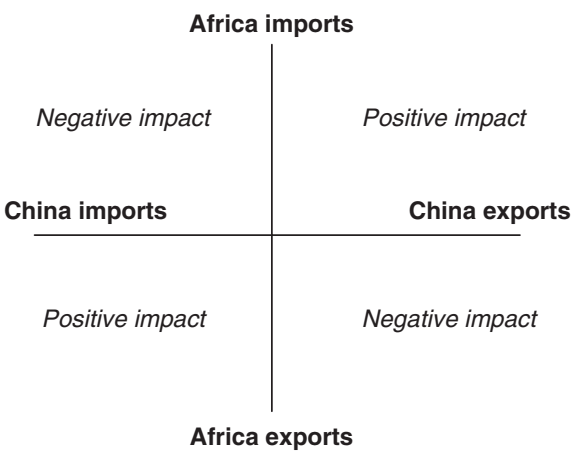

Figure 1: Positive and negative, direct and indirect impact of China-Africa trade relations. 
accords with other analyses of China-Africa trade relations (Kaplinsky and Morris, 2008). However, they take the argument further by also showing the growing displacement by China of African producers in intra-regional trade. The third trade-focused paper (Villoria) addresses the potential for agricultural exports by southern African economies to China in the context of the likely growth of China's growing food imports, and in the context of potential global pressure on food supplies. It documents the virtual non-existence of these agricultural exports, despite the agricultural-intensity of the exports of many of these southern African economies. There is little complementarity between southern Africa's existing agricultural specialisation and China's growing food needs. The paper also explores the potential benefit to African exporters (but, not to African agricultural importers) of rising global food prices arising from China's growing imports, but finds that these are likely to be negligible.

The value added of the two papers on Chinese foreign direct investment (FDI) in subSaharan Africa is that they begin to unpack the China side of this bilateral relationship. Drawing in part on the AERC Scoping Studies, but also utilising other data sources, Kaplinsky and Morris identify four categories of Chinese investors in Africa - centralstate-owned firms, provincial-state-owned firms, Chinese private firms incorporated in China, and small firms operating in Africa owned by independent Chinese 'migrants'. Each of these categories of investors has distinct characteristics, but the two sets of stateowned firms can be distinguished from their western competitors by being closely and strategically bundled in aid and trade links. The authors suggest that African countries need to develop a similar strategic and bundled approach towards these large investors, even if this flies in the face of much of the current Washington Consensus agenda. Gu's contribution is based on the third category of these foreign investors, namely 'private' Chinese firms incorporated in China. Her work is pathbreaking in that, uniquely, it is based on interviews in both China and Africa with Chinese entrepreneurs, as well as with African policy-makers. Her two primary research findings are that many of these Chinese investors are drawn to Africa by intense competition in the Chinese domestic market, and that contrary to much of the current conventional wisdom, the Chinese state offers little support to these private investors, in sharp contradistinction to the state-owned enterprises addressed in the Kaplinsky-Morris paper.

Mohan's paper on Chinese migrants relates in part to the fourth category of foreign investors. He documents the long-lived presence of Chinese migrants in some African economies (such as South Africa and Mauritius) and, recognising the speculative nature of the data, assembles numbers from a variety of sources to show the very large number of Chinese now living and working in Africa. Like $\mathrm{Gu}$, this paper is distinctive in focusing not just on the African side of the China-Africa relationship, but also on the drivers of China's outward flow. Mohan concludes that most contacts with African populations are based on the presence of Chinese migrants in the retail sector. Despite generally harmonious relations between the migrants and the indigenous population, this possibly portends a future of conflict, as has emerged in recent years in the case of Zambia (as documented in the paper by Kragelund). Flowing from Mohan's identification of the growing role of Chinese migrants in Africa in the retail sector is the role of Chinese migrants operating in the services sector. Ndjio's contribution discusses the presence of Chinese prostitutes in the Cameroons. Aside from the richness of his ethnographic research, the distinctive contribution of his paper is that he situates the 'production' and delivery of these particular services in the context of China's exports of manufactures to Africa. These span the spectrum of consumer incomes, but include 'low-quality' products 
(such as cheap and tinny radios), which are often scorned by the African elite, but provide access to low-cost consumer goods for the very poor. He documents a similar process with regard to Chinese prostitution in West Africa, and links this to what he believes is the increasing adverse reaction among Africans to low quality products from China which squeeze out Africa's small scale and informal sector producers. This echoes Kragelund's observation of the adverse reaction to Chinese retailers in Zambia.

Ancharaz and Kragelund address the country-specific impact of China's growing presence in Africa with respect to Mauritius and Zambia, respectively. Ancharaz's conclusions stand out from much of the literature on China and Africa. Contrary to the view that Africa's manufacturing sector will be adversely affected in third-country markets, Ancharaz shows how Mauritian clothing and textile firms have reconfigured their operations by simultaneously changing their product profile and by outsourcing some of the low value-added assembly operations to Madagascar. Mauritius also gains from Chinese aid in construction and infrastructure. Significantly, as Brautigam has shown (Brautigam, 2008), Chinese operations in Mauritius are based on a more than centurylong presence of Chinese immigrants in the country, providing added interest to Mohan's documentation of the growing number of Chinese migrants in Africa. Kragelund's analysis of Chinese investments in Zambia draws together a number of data sources and complements this with primary research to illustrate the rapid spread of Chinese firms. By 2006, China had become the largest foreign investor in Zambia, with 184 documented investments. Like Ancharaz, Kragelund departs from orthodoxy and questions the 'specialness' of Chinese investment. He concludes that Chinese investors are very similar in character to other foreign investors. But the rapid pace of incoming investment (and, as Mohan and Ndjio point out, their 'face' in the service sector) has meant that Chinese FDI has become a potent political factor and that it consequently surfaced as an electoral issue. Although the political opposition subsequently softened its opposition to Chinese investors, Kragelund accords with Mohan in suggesting the potential for future conflict.

The final paper in this Special Issue addresses the European response to China's growing presence in Africa. Wissenbach, an employee of the EU's Development Division, addresses the potential for trilateral cooperation between China, the EU and African governments in meeting the developmental challenge in Africa. The EU believes there is fertile ground for productive cooperation, but it is not clear that the Chinese (or indeed African governments) share this view.

In sum, then, each of the papers in this Special Issue focuses on the dynamics of ChinaAfrica relations. Most of the contributions take the literature forward in that the categories of 'China' and 'Africa' are disaggregated. Some African countries have relatively long-lived relations with China; some have commodities which are a major attraction to China; some possess commodities which are of little use to Chinese consumers; and some African countries have relatively large manufacturing sectors which are, potentially, very vulnerable to direct and indirect competition from the Chinese. Some Africans are producers (for example those in the garments sector displaced by Chinese imports), and others are consumers (for example, those who benefit from the availability of cheap Chinese apparel). Similarly, Chinese actors in Africa are not homogeneous, and despite widespread prejudice, the Chinese state does not pull the strings which bind Chinese actors in synchronised steps, belying the oft-used phrase that 'China has a strategy for Africa'.

An understanding of the nature of the disaggregated social and political actors in both China and Africa is important in explaining how the reception to China's presence is 
changing. In general northern observes tend to focus on its negative impact, for example in undermining the Paris Declaration and the Accra Agenda on aid transparency; northern NGOs focus on poor environmental practices and weak labour standards. Northern firms and governments are also reacting adversely to Chinese competition, as in the case of the International Monetary Fund (IMF's) attempt to block China's large and comprehensive new investments in the Democratic Republic of the Congo (chronicled by Kaplinsky and Morris). By contrast the views in Africa are more diverse. For many, particularly the political class, China represents opportunity. It's a 'new boy on the block', providing not just new styles of working (for example, the rapid completion of infrastructure projects, unencumbered by many of the environmental concerns of northern governments), but new sources of capital. However, the increasingly widespread presence of Chinese migrants working in the small scale and often informal services sectors is beginning to be reflected in opposition to their presence from low income Africans, notwithstanding the fact that they benefit in many ways from the low-cost goods and services provided by the Chinese migrants. The political consequences of China's rapidly growing presence are unfolding and are at an early stage of development. Perhaps China's presence in Africa is at a deceptively calm stage - will 'the ugly American' transform into 'the ugly China'?

Finally, what is clear from all of the papers in this Special Issue is that an analytical understanding of the China-Africa relationship cannot be developed within the boundaries of a single discipline. Economic analysis has much to offer, but as Ancharaz shows particularly clearly, political agency is central to the understanding of how Africa - or more accurately, key political and class groupings in Africa - are not powerless. A reincarnation of dependency theory, in which Africa was seen as a quivering victim of external forces, must be abandoned, both in order to understand better what is happening and why it is happening, and in helping Africa to make the best of the opportunities opened up by the rapid emergence of the Asian Driver economies and the consequent restructuring of the global order in the twenty-first Century.

\section{Note}

1. Three of the contributions in this Special Issue are developments from the AERC's Asian Driver programme, notably Ojeyide-Bankole-Adewuye, Kaplinsky-Morris and Ancharaz.

\section{References}

Alden, C. (2007) China in Africa. London: Zed Books.

Brautigam, D. (2008) 'Flying geese' or 'hidden dragon'? Chinese business and African industrial development. In: D. Large, J.C. Alden and R.M.S. Soares de Oliveira (eds.) China Returns to Africa: A Rising Power and a Continent Embrace. London: Christopher.

Broadman, H. (2007) Africa's Silk Road: China and India's New Economic Frontier. Washington DC: The World Bank.

Dobler, G. (2008) Solidarity, xenophobia and the regulation of Chinese businesses in Namibia. In: C. Alden, D. Large, and R. Soares de Oliveira (eds.) China Returns to Africa: A Rising Power and a Continent Embrace. London: Hurst, pp. 237-255.

Ho, C. (2008) The 'doing' and 'undoing' of community: Chinese networks in Ghana. China Aktuell 3: $45-76$.

Hsu, E. (2007) Zanzibar and its Chinese communities. Populations, Space and Place 13: 113-124. 
Jenkins, R. and Edwards, C. (2004) How does China's growth affect poverty reduction in Asia, Africa and Latin America? Expanded Report to DFID. Norwich, UK: Overseas Development Group, University of East Anglia.

Kaplinsky, R. and Morris, M. (2008) Do the Asian drivers undermine export-oriented industrialisation in SSA. World Development Special Issue on Asian Drivers and their Impact on Developing Countries 36(2): 254-273.

Large, D., Alden, J.C. and Soares de Oliveira, R.M.S. (eds.) (2008) China. Returns to Africa: A Rising Power and a Continent Embrace. London: Christopher.

Tull, D. (2006) China's engagement in Africa: Scope, significance and consequences. Journal of Modern African Studies 44(3): 459-479.

Olusanya Ajakaiye

Director of Research, African Economic Research Consortium,

Nairobi, Kenya.

Raphael Kaplinsky

Professor of International Development, Open University,

Milton Keynes, UK.

E-mail: R.Kaplinsky@open.ac.uk 